\title{
MENGGUMULI TEOLOGI PASTORAL YANG RELEVAN BAGI INDONESIA
}

\author{
Daniel Susanto*
}

\begin{abstract}
Abstrak: Teologi pastoral di Indonesia diwarisi dari Barat. Para teolog pastoral di Indonesia perlu mengembangkan teologi pastoral yang relevan dengan konteks Indonesia, karena konteks masyarakat Indonesia tidak sama dengan konteks masyarakat Barat. Tulisan ini merupakan sebuah upaya untuk menggumuli teologi pastoral yang relevan bagi Indonesia. Upaya ini berangkat dari pemahaman tentang Gereja di Indonesia yang bersifat terbuka dan melayani. Dalam rangka pembagian teologi ke dalam cabang-cabangnya secara tradisional, teologi pastoral di Indonesia dapat dipandang sebagai salah satu bidang studi atau cabang teologi yang mempelajari teori dan praktik pelayanan pastoral. Di samping itu, teologi pastoral merupakan salah satu bentuk refleksi teologi yang bersifat kontekstual. Metode korelasi merupakan metode berteologi pastoral yang revelan bagi Indonesia, karena dalam metode ini proses berteologi pastoral dimulai dari pengalaman pastoral sehingga lebih dekat dengan realitas, tetapi metode ini tidak melupakan peranan berita Kristiani. Agar refleksi teologi pastoral mempunyai jangkauan yang luas, pemahaman tentang pelayanan pastoral di Indonesia harus bersifat holistik yang mencakup perspektif individu, masyarakat, dan lingkungan hidup.
\end{abstract}

Kata-kata kunci: Gereja, teologi pastoral, pengertian tentang teologi pastoral, metode deduktif, metode induktif, metode korelasi, pelayanan pastoral holistik.

Abstract: Pastoral theology in Indonesia has been inherited from the West. Because the Indonesian context is not the same as that of Western society, theologians in Indonesia need to develop a pastoral theology that is relevant to the Indonesian context. This article is an effort to engage pastoral theology in a way that is relevant to Indonesia. This effort takes its point of departure from an understanding of the church

* Daniel Susanto, Sekolah Tinggi Teologi Jakarta, Jalan Proklamasi 27, Jakarta 10320. Email: daniel.susanto@ymail.com 
in Indonesia, which is open and serving. In relation to the traditional understanding of theology and its branches, pastoral theology in Indonesia can be understood as a field of study concerning the theory and practice of pastoral ministry. In addition, pastoral theology is a form of contextual theological reflection. Correlation is a pastoral theological method relevant to Indonesia, because in this method the process of theology starts from pastoral experience. Thus, it is closer to the reality of Indonesian life; but this method does not ignore the Christian message. In order to gain a wider pastoral theological perspective, the understanding of pastoral ministry in Indonesia must be holistic, which includes individual, societal, and environmental perspectives.

Keywords: Church, pastoral theology, understanding of pastoral theology, deductive method, inductive method, method of correlation, holistic pastoral ministry.

\section{PENDAHULUAN}

Teologi pastoral adalah bidang studi teologi yang relatif baru bila dibandingkan dengan bidang-bidang studi teologi lainnya. Walaupun Gerben Heitink menyatakan bahwa bentuk elementer dari teologi pastoral sudah ada dalam Perjanjian Baru, ${ }^{1}$ namun demikian menurut Heitink, penggunaan istilah "teologi pastoral" dalam Protestantisme untuk pertama kalinya baru muncul pada pertengahan abad ke-18. ${ }^{2}$ Menurut Seward Hiltner buku pertama yang menggunakan istilah "teologi pastoral" sebagai judulnya baru ada pada 1749 , yaitu buku C.T. Seidel yang berjudul Pastoral-Theologie. ${ }^{3}$

Bidang studi ini kadang-kadang kurang dipahami dengan baik. Sebagai contoh, ada orang yang menyamakan teologi pastoral dengan pelaya-

1 Gerben Heitink, Praktische theologie: geschiedenis, theorie, handelingsvelden (Kampen: Uitgeverij Kok, 1993), p. 96. Pada halaman 96-98 dari buku ini Heitink juga membahas bentuk-bentuk elementer dari teologi pastoral yang ada dalam Kisah Para Rasul, suratsurat Paulus, termasuk surat-surat pastoral (Timotius dan Titus), dan sebagainya.

2 Seward Hiltner, Preface to Pastoral Theology (Nashville, Tennessee: Abingdon Press, 1958), p. 43.

3 Seward Hiltner, Preface to Pastoral Theology, p. 224. 
nan pastoral; padahal keduanya tidak sama. Ada juga para pelayan pastoral yang kurang mempedulikan betapa pentingnya teologi pastoral bagi pelayanan mereka. Ada yang menyamakan teologi pastoral dengan psikologi pastoral, dan seterusnya.

Sama seperti cabang-cabang teologi lainnya, teologi pastoral di Indonesia diwarisi dari Barat. Teologi yang berasal dari Barat ini belum tentu sesuai untuk Indonesia sebab konteks kita di Indonesia tidak sama dengan konteks masyarakat Barat; oleh karena, itu dalam tulisan ini akan dikemukakan sebuah pergumulan untuk mengupayakan teologi pastoral yang relevan bagi Indonesia. Teologi pastoral yang relevan bagi Indonesia adalah teologi pastoral yang berangkat dari kenyataan hidup Gereja di Indonesia dan yang sesuai dengan konteks Indonesia sehingga dapat menjawab berbagai persoalan dan tantangan yang ada di Indonesia.

Untuk membahas teologi pastoral yang relevan bagi Indonesia, dalam artikel ini akan dikemukakan empat hal. Pertama, Gereja di Indonesia yang terbuka dan melayani. Kedua, pengertian teologi pastoral yang ada dan yang relevan bagi Indonesia. Ketiga, metode berteologi pastoral yang ada dan yang sesuai untuk Indonesia. Keempat, pelayanan pastoral yang dapat menjawab berbagai persoalan yang ada di Indonesia.

\section{GEREJA DI INDONESIA YANG TERBUKA DAN MELAYANI}

Gereja pada dasarnya dimengerti sebagai persekutuan orang-orang yang percaya kepada Tuhan Yesus. Dalam Dokumen Keesaan Gereja Persekutuan Gereja-gereja di Indonesia (DKG-PGI) 2009-2014 dikatakan bahwa Roh Kudus menghimpun umat-Nya dari segala bangsa, suku, kaum, dan bahasa, ke dalam suatu persekutuan yaitu Gereja, yang di dalamnya Kristus adalah Tuhan dan Kepala (Ef. 4:3-16; Why. 7:9). ${ }^{4}$

Orang-orang yang disatukan Roh Kudus di dalam Gereja-Nya ini dipanggil untuk bersekutu, bersaksi, dan melayani. Hal ini ditegaskan

4 Persekutuan Gereja-gereja di Indonesia, Dokumen Keesaan Gereja: Persekutuan Gerejagereja di Indonesia (DKG-PGI) 2009-2014 (Jakarta: Persekutuan Gereja-gereja di Indonesia, 2010), hlm. 112. Untuk selanjutnya disingkat DKG-PGI 2009-2014 bila dokumen ini digunakan dalam tubuh artikel. 
dalam DKG-PGI 2009-2014 yang menyatakan bahwa hakikat dan tugas panggilan serta pengutusan Gereja adalah "keesaan" (upaya penyatuan Gereja atau oikoumene), kesaksian, dan pelayanan dalam kasih. ${ }^{5}$

Untuk dapat menjalankan tugas panggilan dan pengutusannya ini, Gereja di Indonesia harus menjadi Gereja yang terbuka. Apa artinya? Pertama, Gereja yang terbuka bukanlah Gereja yang hanya memikirkan atau mementingkan dirinya sendiri. Persekutuan antaranggota di dalam Gereja memang penting, tetapi persekutuan ini bukanlah persekutuan yang tertutup dan hanya memikirkan dirinya sendiri, melainkan persekutuan yang bersifat terbuka kepada dunia sekitarnya. Dalam DKG-PGI 2009-2014 ditekankan bahwa Gereja tidak hidup untuk dirinya sendiri. Sama seperti Kristus telah meninggalkan kemuliaan-Nya di surga, mengosongkan diri, dan menjadi manusia (Yoh. 1:14; Flp. 2:6-8), dan tergerak hati-Nya oleh belas kasihan kepada semua orang yang sakit, lelah dan terlantar seperti domba tanpa gembala, demikian pulalah Gereja dipanggil untuk selalu menyangkal diri dan mengorbankan kepentingannya sendiri, agar semua orang yang menderita karena pelbagai penyakit dan kelemahan yang merindukan kelepasan, dapat mengalami pembebasan dan penyelamatan Allah dalam Yesus Kristus (Mat. 9:35-38; Luk. 4:18-19). ${ }^{6}$

Kedua, Gereja yang terbuka adalah Gereja yang mau berkomunikasi dan belajar dari yang lain. Sumber belajar Gereja yang utama adalah memang Firman Tuhan, namun sebagai persekutuan dari orang-orang yang tidak sempurna di dunia ini, pengalaman belajar dari yang lain juga dapat memperkaya kehidupan Gereja, misalnya melalui dialog. Berbicara tentang dialog, Ignatius L. Madya Utama mengatakan bahwa untuk menjalankan tugas pengutusannya secara efektif, Gereja perlu melakukan dialog kehidupan dengan kaum miskin (pembebasan), dialog dengan kebudayaan-kebudayaan setempat (inkulturasi), serta dialog dengan berbagai macam tradisi keagamaan (dialog antarpengikut agama-agama). ${ }^{7}$

5 Persekutuan Gereja-gereja di Indonesia, Dokumen Keesaan Gereja, hlm. 44.

6 Persekutuan Gereja-gereja di Indonesia, Dokumen Keesaan Gereja, hlm. 112-113.

7 Ignatius L. Madya Utama, Gereja Partisipatif (Yogyakarta: Pusat Pastoral Yogyakarta, 2010), hlm. 32-33. 
Ketiga, Gereja yang terbuka adalah Gereja yang mau bekerjasama dengan yang lain. Di dalam melakukan pelayanannya, Gereja perlu bekerjasama dengan umat beragama lain, dengan pemerintah, atau dengan masyarakat di mana Gereja itu berada. Dalam DKG-PGI 2009-2014 dinyatakan bahwa dalam usahanya mewujudkan tugas penggilannya untuk memberi kesaksian di tengah-tengah masyarakat majemuk, Gereja hendaklah membina hubungan dan kerjasama dengan semua golongan termasuk dengan umat beragama lain. Kerja sama itu dikembangkan sesuai dengan dasar dan jiwa negara Pancasila di dalam rangka tanggung jawab membangun masyarakat berkeadaban dan bermoral tinggi. ${ }^{8}$ Pelayanan terhadap masyarakat - misalnya pelayanan untuk menanggulangi masalah kemiskinan, bencana alam, pelestarian lingkungan hidup, dan sebagainya-dapat menjadi lebih efektif dan efisien bila dikerjakan bersama dengan pihak lain.

Keempat, Gereja yang terbuka adalah Gereja yang mau mendengarkan saran dan menerima kritik dari yang lain. Tentu tidak semua saran dan kritik itu harus diterima, sebab semua masukan itu harus diuji kebenarannya dan dipertimbangkan dengan baik. Sehubungan dengan hal ini, Gereja harus peka terhadap lingkungan di sekitarnya.

Kelima, Gereja yang terbuka adalah Gereja yang mau menerima perkembangan ilmu pengetahuan dan teknologi. Ilmu pengetahuan dan teknologi adalah berkat Tuhan yang dapat digunakan untuk meningkatkan kesejahteraan hidup manusia. Berbagai kemajuan dalam dunia teknologi dan informasi dapat dimanfaatkan dalam pelayanan, di samping harus disikapi secara kritis.

Keterbukaan sangat penting bagi Gereja Tuhan di Indonesia. Dalam DKG-PGI 2009-2014 ditegaskan bahwa Gereja dituntut untuk selalu terbuka kepada dunia ini, agar dunia ini terbuka kepada undangan Allah untuk turut serta di dalam arak-arakan orang yang beriman kepada Tuhan

8 Persekutuan Gereja-gereja di Indonesia, Dokumen Keesaan Gereja, hlm. 73. 
Yesus menuju pemenuhan janji Allah mengenai Kerajaan-Nya di dalam Yesus Kristus (1Ptr. 2:9-10; 3:15-16). ${ }^{9}$

Selain bersifat terbuka, Gereja di Indonesia dipanggil Allah untuk melayani. Pelayanan yang dimaksud di sini adalah pelayanan terhadap sesama dan pelayanan untuk menjaga kelestarian lingkungan hidup.

Pelayanan terhadap sesama merupakan tugas yang diberikan Tuhan kepada Gereja-Nya. Dalam DKG-PGI 2009-2014 disebutkan bahwa Gereja berperan-serta dan melayani dalam kehidupan masyarakat, bangsa dan negara Pancasila untuk menghadirkan tanda-tanda Kerajaan Allah, yaitu kesejahteraan, keadilan, kebebasan, persaudaraan, perdamaian, hukum yang berkeadilan, dan kemanusiaan yang dikehendaki Tuhan untuk dunia ini. ${ }^{10}$ Pelayanan untuk menjaga kelestarian lingkungan hidup juga merupakan tugas yang Tuhan karuniakan kepada Gereja-Nya. Dalam DKGPGI 2009-2014 disebutkan bahwa sebagai manifestasi pelaksanaan tugas Gereja untuk memberitakan Injil kepada segala makhluk, setiap orang yang beriman kepada Tuhan Yesus bertanggungjawab bagi terpeliharanya keutuhan ciptaan. Dengan demikian setiap orang yang beriman kepada Tuhan Yesus mestinya menjadi hamba-hamba Allah yang sadar lingkungan dan berperan aktif dalam memelihara kelestariannya.

Untuk dapat melakukan pelayanannya secara relevan, Gereja di Indonesia perlu mengenali dan mempelajari persoalan-persoalan yang ada di Indonesia. Dalam orasi dies natalis ke-72 Sekolah Tinggi Teologi Jakarta, penulis pernah membahas beberapa persoalan yang dihadapi bangsa Indonesia pada masa transisi setelah rezim Orde Baru tumbang. Beberapa persoalan yang membutuhkan tanggapan pastoral dari Gereja pada waktu itu adalah persoalan kebebasan yang berlebihan; persoalan kekerasan; persoalan kemiskinan; persoalan korupsi; persoalan konflik sosial; persoalan nilai-nilai moral, karakter, dan perilaku manusia; persoalan stres dan gangguan mental; dan persoalan bencana alam. ${ }^{11}$

9 Persekutuan Gereja-gereja di Indonesia, Dokumen Keesaan Gereja, hlm. 113.

10 Persekutuan Gereja-gereja di Indonesia, Dokumen Keesaan Gereja, hlm. 81.

11 Daniel Susanto, Pelayanan Pastoral di Indonesia pada Masa Transisi - Orasi Dies Natalis ke-72 Sekolah Tinggi Teologi Jakarta (Jakarta: UPI STT Jakarta, 2006), hlm. 13-22. 
Menyikapi persoalan-persoalan yang ada, Gereja-gereja di Indonesiamelalui DKG-PGI 2009-2014-menjabarkan berbagai macam pelayanan yang dapat dilakukan oleh Gereja-gereja di Indonesia. Secara garis besar dikatakan bahwa Gereja-gereja di Indonesia dipanggil untuk melakukan pelayanan, yaitu berperan-serta dan melayani dalam masyarakat yang sedang berada dalam proses mewujudkan masyarakat berkeadaban dengan memberi tekanan pada keadilan, pelayanan dan penegakkan HAM, harkat dan martabat manusia. ${ }^{12}$

Ignatius L. Madya Utama, mengingatkan agar Gereja meneladan Yesus sendiri: hadir di tengah-tengah masyarakat, mendengarkan "impian" dan kebutuhan masyarakat, membangun solidaritas dengan mereka, serta mewartakan karya agung Allah lewat kesaksian hidupnya. ${ }^{13}$ Untuk itu Gereja tidak boleh hanya melakukan ibadahnya secara "vertikal," tetapi juga secara "horisontal" melalui pelayanannya, dengan memberikan perhatian yang besar kepada orang-orang miskin dan kaum lemah yang tersingkirkan, penegakan hukum dan HAM, kepedulian terhadap persoalan-persoalan ekologis, keterlibatan aktif dalam menciptakan sebuah masyarakat yang lebih manusiawi, dan sebagainya. ${ }^{14}$

Dengan uraian singkat tentang Gereja di Indonesia yang terbuka dan melayani, menjadi jelaslah bahwa teologi pastoral yang dibutuhkan bagi Indonesia saat ini adalah teologi pastoral yang dapat menjawab berbagai persoalan yang dihadapi oleh Gereja dan bangsa Indonesia.

\section{PENGERTIAN TENTANG TEOLOGI PASTORAL}

Apakah yang dimaksud dengan teologi pastoral? Menurut J.R. Burck dan R.J. Hunter, ${ }^{15}$ sekurang-kurangnya terdapat tiga buah pengertian yang berbeda tentang teologi pastoral di kalangan Kristen Protestan.

12 Persekutuan Gereja-gereja di Indonesia, Dokumen Keesaan Gereja, hlm. 48.

13 Ignatius L. Madya Utama, Gereja Partisipatif, hlm. 46.

14 Bdk. Ignatius L. Madya Utama, Gereja Partisipatif, hlm. 46.

15 J.R. Burck \& R.J. Hunter, "Pastoral Theology, Protestant," in Rodney J. Hunter et al., eds., Dictionary of Pastoral Care and Counseling (Nashville; Abingdon Press, 1990), p. 867. Lihat juga Daniel Susanto, "Sekilas tentang Teologi Pastoral di Indonesia," dalam 
Pertama, secara tradisional, teologi pastoral dipandang sebagai cabang teologi yang merumuskan prinsip-prinsip, teori-teori, dan prosedur-prosedur praktis bagi pelayanan pendeta dalam semua fungsinya (walaupun pada abad ke-19 homiletika sering tidak dimasukkan). Dalam pemahaman ini pelayanan pendeta menjadi fokus atau pusat perhatian dari teologi pastoral.

Kedua, teologi pastoral merupakan bidang studi teologi praktis tentang teori dan praktik pelayanan dan konseling pastoral (atau: penggembalaan). Di samping studi tentang metode menolong dan menyembuhkan, bidang studi ini juga mencakup studi tentang kehidupan dan perkembangan moral dan religius, teori kepribadian, hubungan interpersonal dan hubungan dalam keluarga, serta masalah-masalah khusus seperti penyakit, kedukaan, dan rasa bersalah.

Ketiga, teologi pastoral adalah salah satu bentuk refleksi teologis di mana pengalaman pastoral berfungsi sebagai suatu konteks bagi perkembangan kritis dari pengertian teologis yang mendasar. Teologi pastoral, dalam pengertian ini, memusatkan perhatiannya pada pokok-pokok pembahasan seperti penyakit, kematian, seksualitas, keluarga, kehidupan pribadi, dan topik-topik teologis yang dipertimbangkan dari perspektif pastoral seperti iman, pengharapan, kasih, keselamatan, dan Allah. Di sini teologi pastoral tidak dipandang sebagai teologi tentang penggembalaan, tetapi suatu tipe teologi kontekstual: suatu upaya berteologi yang dilakukan secara pastoral. Teologi pastoral dalam pengertian ini akan melengkapi pengertian-pengertian tentang teologi pastoral yang lain.

Pandangan para teolog pastoral tentang teologi pastoral, baik di dunia maupun di Indonesia, juga tidak sama. Ada teolog yang mempunyai pemahaman tentang teologi pastoral seperti pengertian pertama, ada yang seperti pengertian kedua, dan ada pula yang seperti pengertian ketiga. Berikut adalah contoh dari para teolog tersebut.

Bunga Rampai Teologi dan Pelayanan Pastoral, diedit oleh Daniel Susanto (Jakarta: Majelis Jemaat GKI Menteng Jakarta, 2003), hlm. 6-7. 
Pengertian tradisional tentang teologi pastoral misalnya dianut oleh Thomas C. Oden dari Amerika Serikat dan Peter Wongso dari Indonesia. Di dalam bukunya yang berjudul Pastoral Theology: Essentials of Ministry, Oden menyatakan bahwa teologi pastoral adalah cabang dari teologi Kristen yang berhubungan dengan jabatan dan fungsi pendeta. ${ }^{16}$ Karena teologi pastoral dikaitkan dengan jabatan dan fungsi pendeta, di dalam bukunya ini Oden membahas tentang bagaimana menjadi pendeta dan tugas-tugas apa saja yang dilakukan oleh pendeta, seperti misalnya melayani ibadah, berkhotbah, mengajar, melakukan pendampingan pastoral, dan sebagainya. ${ }^{17}$

Pandangan Peter Wongso dari Indonesia tentang teologi pastoral tidak berbeda dengan pandangan Oden. Menurut Wongso, teologi penggembalaan adalah salah satu mata pelajaran teologi praktis. Lingkup pembahasannya meliputi dua bagian besar, yaitu bagaimana menggembalakan Gereja dan bagaimana mengajar orang Kristen..$^{18}$ Di dalam bukunya yang berjudul Theologia Penggembalaan, ${ }^{19}$ Wongso membahas panjang lebar tentang pendeta dan tugas pelayanan yang dilakukannya, seperti memimpin administrasi, memimpin kebaktian, memimpin sakramen, melakukan kunjungan penggembalaan, dan sebagainya. Dengan perkataan lain, pendeta dan tugas pelayanan pendeta merupakan fokus dari tulisan Peter Wongso tentang teologi penggembalaan.

Sebagian besar teolog pastoral di Indonesia memahami pengertian teologi pastoral sebagai bidang studi teologi praktis tentang teori dan praktik pelayanan dan konseling pastoral. Sebagai contoh, Abineno. Ia berpendapat bahwa dalam pembagian teologi ke dalam cabang-cabangnya secara tradisional, bidang yang mencakup pembentukan teori tentang isi dan praktik pastorat disebut teologi pastoral. ${ }^{20}$ Ia juga menyatakan bahwa

16 Thomas C. Oden, Pastoral Theology: Essentials of Ministry (San Francisco: Harper \& Row, 1983), p. x.

17 Thomas C. Oden, Pastoral Theology, pp. v-vi.

18 Peter Wongso, Theologia Penggembalaan (Malang: Seminary Alkitab Asia Tenggara, 1991), hlm. 1.

19 Peter Wongso, Theologia Penggembalaan, hlm. 1-129.

20 J.L.Ch. Abineno, Pedoman Praktis untuk Pelayanan Pastoral (Jakarta: BPK Gunung Mulia, 1993), hlm. 16. 
teologi pastoral itu merupakan bagian dari teologi praktika, sedangkan teologi praktika adalah teologi yang membicarakan tentang pelayanan Gereja di berbagai bidang. ${ }^{21}$

Selain Abineno, peserta Studi Institut Persetia tentang Pendidikan Pastoral Klinis-yang sebagian besar terdiri dari dosen-dosen pastoral di Indonesia pada waktu itu - juga merumuskan teologi pastoral sebagai bagian dari ilmu teologi yang memberi dasar teologis bagi pelayanan pastoral. ${ }^{22}$ Dalam Studi Institut Persetia itu juga dicatat bahwa hampir semua sekolah teologi yang mengirimkan utusan mereka pada waktu itu masih mengikuti pola pembagian teologi secara klasik, yang terdiri dari biblika, historika, sistematika, dan praktika. Dalam bidang praktika, hampir semua sekolah teologi mengajarkan mata kuliah teologi pastoral. Mengenai isinya, ternyata ada perbedaan. Ada yang menekankan kuliah pastoral sebagai latihan teoritis dan praktis bagi calon pelayan pastoral sebagai persiapan untuk melakukan tugas-tugas mereka, seperti konseling, visitasi, mengajar, berkhotbah, pelayanan sakramen, diakonia, evangelisasi, dan pengembangan Gereja. Yang lain lebih menekankan mata kuliah ini sebagai analisis teologis tentang masalah-masalah yang muncul dalam pelayanan pastoral dan ada yang menambahkan analisis sosiologis atau psikologis terhadap analisis teologis tersebut. ${ }^{23}$

Pengertian teologi pastoral sebagai salah satu bentuk refleksi teologi dalam konteks pengalaman pastoral belum banyak dianut oleh para teolog pastoral di Indonesia. Hal ini belum terlalu populer di Indonesia. Walaupun demikian, pengertian ini antara lain pernah dikemukakan oleh Tjaard G. Hommes. Di dalam tulisannya ia menyatakan bahwa teologi pastoral merupakan refleksi teologis atas dan dalam konteks pelayanan pastoral. ${ }^{24}$

21 J.L.Ch. Abineno, Pedoman Praktis untuk Pelayanan Pastoral, hlm. 17.

22 “Rangkuman Hasil Lokakarya Theologia Pastoral," dalam Studi Institut Persetia tentang Pendidikan Pastoral Klinis - Salatiga, 2-10 Juni 1990, diedit oleh Phan Bien Ton, Mary Rajapono Manuain, Darmanto (Jakarta: Persetia, 1991), hlm. 67.

23 "Rangkuman Hasil Lokakarya Theologia Pastoral," hlm. 66-67.

24 Tjaard G. Hommes, "Pendahuluan," dalam Teologi dan Praksis Pastoral - Antologi Teologi Pastoral, diedit oleh Tjaard G. Hommes \& Gerrit Singgih (Yogyakarta: Kanisius, 1992), hlm. 17. 
Menjelaskan pandangannya ini, Hommes menyatakan bahwa sebagai salah satu disiplin dari ilmu teologi, teologi pastoral mempunyai kesamaan dengan disiplin-disiplin teologi lainnya, yaitu usaha untuk merefleksikan keberadaan Allah secara kritis, termasuk merefleksikan tindakan Allah di dunia dan di dalam sejarah manusia; namun teologi pastoral juga mempunyai perspektif yang unik. Teologi pastoral merupakan salah satu disiplin teologi yang secara prinsip memfokuskan perhatiannya pada hal-hal yang "pastoral." Yang dimaksud dengan hal-hal yang "pastoral," menurut Hommes, mengacu pada dua hal, yaitu praksis pelayanan Kristen dan dirinya sendiri atau teologi pastoral itu sendiri. ${ }^{25}$ Dengan perkataan lain, teologi pastoral memfokuskan perhatiannya pada pelayanan pastoral dan pengembangan dirinya sendiri sebagai sebuah ilmu.

Bagaimana kita menanggapi pengertian yang ada tentang teologi pastoral seperti yang telah diuraikan sebelumnya bagi pengembangan pengertian teologi pastoral agar relevan bagi Indonesia? Untuk menjawab pertanyaan ini, pertama-tama kita harus mengingat bagaimana corak teologi pastoral kita pada masa lalu. ${ }^{26}$

Teologi pastoral di Indonesia, sama seperti bidang-bidang studi teologi lainnya, pada mulanya diwarisi dari Barat, khususnya dari Belanda dan Jerman. Hal ini disebabkan karena para penginjil yang bekerja di Indonesia pada waktu itu datang dari Barat dan Indonesia pernah dijajah Belanda selama sekitar 350 tahun.

Bagaimana corak teologi yang berasal dari Barat pada waktu itu? Menurut peserta Konsultasi Teologi yang diadakan di Sukabumi pada 1970, teologi yang dibawa oleh para penginjil Barat pada waktu itu diwarnai oleh pietisme. Dengan semangat injili yang besar dalam memberitakan Injil, para penginjil sangat menekankan usaha memenangkan jiwa-jiwa untuk Kristus, pembentukan jemaat-jemaat, kesalehan pribadi, dan keselamatan jiwa. Tugas panggilan orang Kristen di tengah-tengah masyarakat rupanya kurang diperhatikan, sehingga dalam bidang-bidang kemasyara-

25 Tjaard G. Hommes, “Pendahuluan,” hlm. 19-20.

26 Lih. Daniel Susanto, "Sekilas tentang Teologi Pastoral di Indonesia," hlm. 5-6. 
katan tertentu-misalnya perniagaan, usaha-usaha ekonomi dan politik-peranan orang Kristen praktis kurang nampak. ${ }^{27}$

Peserta konsultasi mengamati bahwa dalam perkembangan selanjutnya-dengan bertitik tolak dari alam pemikiran yang pietistis itudikembangkanlah metode yang berkompromi dengan unsur-unsur tradisionalisme dan feodalisme, yang mengakibatkan sifat tertutup pada pemikiran teologi. ${ }^{28}$ Sebagian peserta konsultasi berpendapat bahwa teologi yang diwarisi Gereja-gereja di Indonesia dari badan-badan zending adalah teologi yang berdasarkan pemikiran yang metafisis dan yang oleh karena itu mudah diterima oleh orang Indonesia dahulu yang berpikir secara metafisis, mythis, dan ontologis. ${ }^{29}$

Corak berteologi semacam itu - menurut peserta konsultasi teologi di Sukabumi-cukup kuat pengaruhnya dalam Gereja-gereja di Indonesia, walaupun sudah ada usaha-usaha untuk melepaskan diri dari keadaan yang statis-formalistis itu. ${ }^{30}$ Dalam perkembangan teologi di Indonesia pada saat ini, corak semacam itu makin lama makin ditinggalkan orang. Hal ini juga berlaku bagi pengembangan teologi pastoral di Indonesia.

Seperti telah dikemukakan di atas, pada saat ini di Indonesia terdapat paling sedikit tiga pandangan tentang teologi pastoral. Pandangan mana yang lebih sesuai untuk Indonesia? Menyikapi tiga pandangan tentang teologi pastoral tersebut, pertama-tama harus kita katakan bahwa pandangan pertama, yang memfokuskan teologi pastoral pada pelayanan pendeta, kurang sesuai untuk Indonesia sebab pandangan ini sangat sempit dan hanya berorientasi pada jabatan. Teologi pastoral seharusnya memusatkan perhatiannya pada pelayanan pastoral yang dilakukan oleh semua anggota Gereja, baik pejabat maupun bukan pejabat gerejawi. Keterbatasan jumlah pejabat gerejawi di Indonesia juga menyebabkan perlunya dikembangkan sebuah teologi pastoral yang lebih bersifat terbuka.

27 S.A.E. Nababan, ed., Pergumulan Rangkap: Laporan Konsultasi Theologia, Sukabumi 2328 Nopember 1970 (Jakarta: Sekretariat Umum DGI, 1971), hlm. 13.

28 S.A.E. Nababan, ed., Pergumulan Rangkap, hlm. 14.

29 S.A.E. Nababan, ed., Pergumulan Rangkap, hlm. 14.

30 S.A.E. Nababan, ed., Pergumulan Rangkap, hlm. 14. 
Pandangan kedua, yang menyatakan bahwa teologi pastoral merupakan bidang studi teologi praktis tentang teori dan praktik pelayanan serta konseling pastoral, patut mendapat perhatian bagi pengembangan pengertian tentang teologi pastoral yang relevan bagi Indonesia. Mengapa demikian? Pertama, dalam rangka meletakkan kedudukan teologi pastoral dalam pembagian teologi ke dalam cabang-cabangnya secara tradisional, teologi pastoral memang merupakan salah satu bidang studi atau cabang dari teologi yang mempelajari teori dan praktik pelayanan pastoral, yang di dalamnya terdapat konseling pastoral. Sebagai salah satu cabang teologi praktika, teologi pastoral disebut sebagai poimenik. Kedua, pandangan ini menyatakan bahwa pelayanan pastoral sebagai isi studi teologi pastoral dan tidak hanya konseling pastoral saja. Konseling pastoral memang dipelajari dalam teologi pastoral, tetapi studi teologi pastoral lebih luas dari pada pembicaraan tentang konseling pastoral. Ketiga, pandangan ini tidak hanya menekankan teori, tetapi juga praktik pelayanan pastoral.

Pandangan ketiga, yang memandang teologi pastoral sebagai salah satu bentuk refleksi teologi pastoral kontekstual, juga harus kita perhatikan. Pandangan ini memperluas teologi pastoral dari bidang studi menjadi suatu perspektif teologi yang berangkat dari pengalaman pastoral dan yang bersifat kontekstual. Dengan pandangan yang ketiga ini, di samping membicarakan tentang teori dan praktik pelayanan pastoral, teologi pastoral juga bertugas merefleksikan secara teologis kontekstual pengalaman pelayanan pastoral dan pengalaman-pengalaman lain yang menantang tanggapan pastoral. Refleksi ini akan membantu pelayanan pastoral dan sangat mewarnai bagaimana pelayanan pastoral nanti dilaksanakan.

Teologi pastoral biasanya berangkat dari pengalaman pastoral. Pengalaman pastoral di Indonesia tentu tidak sama dengan pengalaman pastoral yang ada di Barat. Begitu juga dengan kondisi dan persoalan yang ada di Indonesia. Oleh karena itu, teologi pastoral yang sesuai bagi Indonesia adalah teologi pastoral yang dapat menjawab kebutuhan Gereja dan masyarakat Indonesia, seperti yang akan dibicarakan lebih lanjut. 


\section{METODE TEOLOGI PASTORAL}

Sebagai salah satu bentuk refleksi teologis, teologi pastoral mengenal paling tidak metode deduktif, metode induktif, dan metode korelasi. ${ }^{31}$

Yang dimaksud dengan metode deduktif adalah metode berteologi pastoral yang menerapkan teori-teori teologis tertentu ke dalam praktik pastoral. Yang ditekankan dalam metode ini adalah bagaimana menerapkan teori ke dalam praktik. Dalam metode ini, peran ilmu-ilmu lain seperti psikologi, antropologi, sosiologi, dan sebagainya memang diperlukan. Namun peranan ilmu-ilmu ini hanya berfungsi untuk membantu menganalisis situasi agar teori dapat diterapkan sesuai dengan situasi yang ada. Ilmu-ilmu tersebut tidak memberikan pengaruh bagi pembentukan teori. Dalam metode ini pengalaman pastoral atau praktik pastoral juga tidak memberikan pengaruh bagi pembentukan atau pengembangan teori.

Metode teologi pastoral yang merupakan kebalikan dari metode yang pertama adalah metode induktif. Dalam metode ini praksis pelayanan pastoral mempunyai arti yang sangat penting. Kebenaran-kebenaran teologis ditemukan di tengah-tengah konteks yang nyata. Dalam metode ini titik berangkat berteologi pastoral bukan teori, tetapi praktik pelayanan pastoral.

Metode yang ketiga adalah metode korelasi. Dalam metode ini refleksi teologi pastoral dilakukan dengan mengkorelasikan pertanyaan-pertanyaan yang ditimbulkan dari situasi dengan jawaban yang diberikan oleh Berita Kristiani. Metode korelasi dikemukakan oleh Paul Tillich, ${ }^{32}$ kemudian direvisi oleh David Tracy.

Di dalam bukunya Systematic Theology, Tillich mengemukakan metode berteologi yang disebut "metode korelasi." Metode ini diharapkan dapat membantu para teolog untuk menjawab pertanyaan-pertanyaan yang ditimbulkan oleh situasi manusia. Tillich menyatakan metode korelasi

31 Daniel Susanto, “Sekilas tentang Teologi Pastoral di Indonesia," hlm. 9-10.

32 Paul Tillich, Systematic Theology, vol. I (Chicago: The University of Chicago Press, 1951), p. 60. 
sebagai metode berteologi yang menjelaskan isi iman Kristen melalui pertanyaan-pertanyaan eksistensial dan jawaban teologis dalam keadaan saling bergantung. ${ }^{33}$ Melalui metode ini Tillich mencoba mengkorelasikan pertanyaan-pertanyaan yang dinyatakan secara tidak langsung dalam situasi tertentu dengan jawaban-jawaban yang dinyatakan secara tidak langsung dalam berita (message).

Apa yang Tillich maksudkan dengan pertanyaan dan jawaban, serta bagaimana keduanya berkorelasi dalam teologi? Menurut Tillich, pertanyaan itu ditimbulkan dari situasi. Situasi di sini tidak sama dengan suatu keadaan, tetapi interpretasi dari suatu eksistensi. Sebagai contoh, situasi bukanlah keadaan retaknya secara politis antara Timur dan Barat, tetapi interpretasi politis terhadap keretakan tersebut. ${ }^{34}$ Materi pertanyaanpertanyaan eksistensial ini diperoleh dari seluruh pengalaman manusia dan ungkapannya yang beraneka ragam. ${ }^{35}$ Bila pertanyaan berasal dari situasi, jawaban berasal dari berita Kristiani (Christian message). Menurut Tillich, berita Kristiani menyediakan jawaban bagi pertanyaan-pertanyaan yang dinyatakan secara tidak langsung dalam eksistensi manusia. ${ }^{36}$

Di dalam metode korelasi, pertanyaan dan jawaban dikorelasikan. Menurut Tillich, dalam bahasa ilmiah, korelasi adalah sebuah kata yang mempunyai beberapa arti. Korelasi dimengerti sebagai keadaan saling bergantung dari dua faktor yang berdiri sendiri. Dalam metode korelasi, pertanyaan dan jawaban adalah masing-masing berdiri sendiri. Walaupun demikian, keduanya juga saling bergantung. Jadi korelasi berarti bahwa, sementara dalam hal-hal tertentu pertanyaan dan jawaban itu berdiri

33 Paul Tillich, Systematic Theology, vol. I, p. 60. Lihat juga Daniel Susanto, “Clinical Pastoral Education: Sebuah Model Pendidikan Pastoral di Indonesia," Jurnal Teologi Proklamasi 8 (Mei 2009): 60.

34 Paul Tillich, Systematic Theology, vol. I, p. 4. Lihat juga Daniel Susanto, “Clinical Pastoral Education," hlm. 61.

35 Paul Tillich, Systematic Theology, vol. II (Chicago: The University of Chicago Press, 1957), p. 15; Lihat pula Daniel Susanto, “Clinical Pastoral Education," hlm. 61.

36 Paul Tillich, Systematic Theology, vol. I, p. 64. Lihat juga Daniel Susanto, “Clinical Pastoral Education," hlm. 61. 
sendiri, dalam hal-hal yang lain keduanya saling bergantung. ${ }^{37}$ Dalam hal apakah keduanya saling bergantung? Menurut Tillich, dalam bentuk dari pertanyaan dan jawaban itu. Bentuk jawaban ditentukan oleh bentuk pertanyaannya, begitu juga bentuk pertanyaan ditentukan oleh bentuk jawabannya. Tillich menegaskan bahwa substansi dari jawaban tidak tergantung pada pertanyaan. Yang bergantung pada pertanyaan hanyalah bentuk dari jawaban teologisnya saja. ${ }^{38}$

Tugas teologi, menurut Tillich, adalah merumuskan pertanyaanpertanyaan dan jawaban-jawaban seperti yang telah diuraikan di atas. ${ }^{39}$ Sebab pertanyaan secara logis lebih dulu ada sebelum jawaban, maka tugas pertama dari teologi adalah merumuskan pertanyaan yang timbul dari pengalaman manusia ketika ia merefleksikan pengalamannya itu. Berlawanan dengan Orthodoksi Protestan, teologi Tillich tidak mulai dari jawaban berita Kristiani, tetapi dari pertanyaan situasi manusia. ${ }^{40}$ Karena mulai dari situasi manusia yang nyata, jawaban teologis yang diberikan tentunya akan lebih relevan.

Dalam metode korelasi Tillich, jawaban teologis diberikan dari sumber, melalui media dan di bawah norma teologi ${ }^{41}$ Menurut Tillich, sumber teologi adalah Alkitab, sejarah Gereja, dan sejarah kebudayaan dan agama. Media teologi adalah pengalaman, sedangkan norma teologi adalah hidup baru (New being) dalam Yesus selaku Kristus. Dalam teologi Tillich, pengalaman mempunyai arti yang sangat penting. Pengalaman adalah media melalui mana sumber-sumber berbicara kepada kita, melalui mana kita dapat menerimanya. ${ }^{42}$ Berita diterima, diwarnai, dan diinter-

37 Paul Tillich, Systematic Theology, vol. II, pp. 13-14. Lihat juga Daniel Susanto, “Clinical Pastoral Education," hlm. 61.

38 Paul Tillich, Systematic Theology, vol. II, p. 15. Lihat juga Daniel Susanto, “Clinical Pastoral Education," hlm. 61.

39 Paul Tillich, Systematic Theology, vol. I, p. 61. Lihat juga Daniel Susanto, “Clinical Pastoral Education," hlm. 61.

40 Paul Tillich, Systematic Theology, vol. I, p. 62. Lihat juga Daniel Susanto, "Clinical Pastoral Education," hlm. 61.

41 Paul Tillich, Systematic Theology, vol. I, p. 64. Lihat juga Daniel Susanto, “Clinical Pastoral Education," hlm. 62.

42 Paul Tillich, Systematic Theology, vol. I, p. 40. Lihat juga Daniel Susanto, “Clinical Pastoral Education," hlm. 62. 
pretasikan melalui pengalaman. Norma juga bertumbuh di dalam pengalaman. ${ }^{43}$ Tanpa pengalaman, sebenarnya tidak mungkin ada teologi, sebab pengalaman adalah seperti udara dengannya teologi bernafas. ${ }^{44}$

Metode korelasi yang dikemukakan Tillich kemudian disempurnakan oleh David Tracy. Menurut Tracy, korelasi yang terjadi antara pertanyaan dan jawaban bersifat timbal balik. Itu berarti antara pertanyaan dan jawaban terdapat hubungan yang saling mempengaruhi. ${ }^{45}$

Metode teologi pastoral yang banyak dipakai para teolog pastoral di Indonesia adalah metode deduktif dan metode korelasi. Metode deduktif telah lama dipakai di Indonesia. Banyak buku teologi pastoral yang ditulis dengan menggunakan metode ini. Namun dalam perkembangan teologi pastoral di Indonesia, metode korelasi juga telah digunakan. ${ }^{46}$

J.B. Banawiratma dan Tom Jacobs pernah melakukan eksperimen proses berteologi yang didasarkan pada metode korelasi. ${ }^{47}$ Proses berteologi tersebut berpangkal pada pengalaman dan melalui komunikasi dengan tradisi-tradisi Kristiani kembali ke pengalaman. Yang dimaksud dengan tradisi Kristiani adalah segala yang mengungkapkan iman kepada Yesus Kristus, pertama-tama Kitab Suci. Di samping itu, yang termasuk tradisi Kristiani adalah ajaran Gereja, tradisi spiritualitas, pewartaan, ibadat, teologi, maupun wujud kehidupan sosial Gereja sepanjang sejarahnya. ${ }^{48}$

Proses berteologi yang dikemukakan oleh Banawiratma dan Jacobs terdiri dari empat momen dan dua belas langkah:49

43 Paul Tillich, Systematic Theology, vol. I, p. 52. Lihat juga Daniel Susanto, “Clinical Pastoral Education," hlm. 62.

44 Paul Tillich, Systematic Theology, vol. II, p. 22. Lihat juga Daniel Susanto, “Clinical Pastoral Education," hlm. 62.

45 David Tracy, "The Foundations of Practical Theology," in Practical Theology edited by Don S. Browning (San Francisco: Harper \& Row, 1980), p. 63.

46 Daniel Susanto, “Sekilas tentang Teologi Pastoral di Indonesia," hlm. 10.

47 J.B. Banawiratma, “Teologi Fungsional - Teologi Kontekstual," dalam Konteks Berteologi di Indonesia: Buku Penghormatan untuk HUT ke-70 Prof. Dr. P.D. Latuihamallo, diedit oleh Eka Darmaputera (Jakarta: BPK Gunung Mulia, 1991), hlm. 53-61.

48 J.B. Banawiratma, “Teologi Fungsional - Teologi Kontekstual,” hlm. 53.

49 J.B. Banawiratma, “Teologi Fungsional - Teologi Kontekstual,” hlm. 55. 
A. Momen pengalaman

Refleksi teologis dimulai dari pengalaman, yang terdiri dari:

1. Mengumpulkan data pengalaman.

Data pengalaman dapat dikumpulkan melalui hidup di tengahtengah situasi konkrit dalam jangka waktu tertentu, angket, wawancara, atau metode penelitian lain yang bersifat ilmiah.

2. Merumuskan pengalaman.

Data pengalaman yang sudah dikumpulkan dan dicatat perlu dirumuskan. Perumusan ini pada umumnya terjadi melalui sharing dalam kelompok. Di sini para peserta ditantang untuk secara objektif merumuskan apa yang dialami.

3. Menganalisis pengalaman dengan bantuan ilmu-ilmu lain (pendekatan interdisipliner).

Objektivikasi data dalam sharing kelompok harus dilanjutkan dengan analisis yang dapat dipertanggungjawabkan. Untuk melakukan hal ini teologi membutuhkan bantuan ilmu-ilmu lain. Sebuah teologi yang fungsional atau kontekstual membutuhkan pendekatan inter-disipliner.

4. Merumuskan fokus refleksi.

Proses teologi yang terbatas harus membatasi bahan dan harus menyadari bahwa refleksinya merupakan sesuatu yang terbatas. Oleh karena itu, dari keseluruhan data pengalaman yang telah diolah sampai sekarang perlu dipilih pokok-pokok yang akan dikembangkan lebih lanjut. Di sini problem areas perlu dicari dan ditemukan.

B. Momen keprihatinan iman

Yang menjadi titik tolak seluruh kegiatan berteologi adalah pengalaman iman. Pada tahap ini realitas iman yang dialami secara eksplisit dijadikan tema refleksi. Momen ini terdiri dari dua langkah, yaitu: 
5. Menemukan tindakan moral dan religius.

Pada langkah ini ditemukanlah tindakan moral dan religius. Keduanya merupakan bentuk dari penyerahan iman.

6. Merumuskan keprihatinan iman: hipotesis.

Keprihatinan iman merupakan reaksi orang beriman dalam situasi hidup nyata yang konkrit. Setelah menganalisa pengalaman secara kritis, dirumuskanlah keprihatinan iman. Perumusan ini dapat menyentuh tindakan moral maupun tindakan religius, tetapi selalu merupakan pengalaman dan sikap iman yang eksistensial dalam hidup nyata yang konkrit. Perumusan di sini merupakan hipotesis atau tesis sementara yang masih harus dikaji secara kritis melalui konfrontasi dengan tradisi-tradisi kristiani.

C. Momen sintesis teologis

Suatu ciri refleksi teologis yang tidak dapat ditinggalkan adalah mendengarkan tradisi-tradisi Kristiani. Tradisi Kristiani di sini dimengerti secara luas, yaitu apa saja yang menampilkan iman kepada Yesus Kristus. Sintesis teologis dicapai melalui momen mendengarkan, yang terdiri dari:

7. Komunikasi dengan tradisi tertulis dari iman Kristiani (tradisi "doktrinal").

Tradisi-tradisi tertulis mempunyai ciri "doktrinal" dan meliputi Kitab Suci, ajaran-ajaran Gereja maupun teologi. Tradisi-tradisi ini harus ditafsirkan dalam konteksnya masing-masing. Melakukan interpretasi konteks "doktrinal" bermaksud untuk berdialog dengan umat Kristiani dalam konteks atau situasi tertentu, mengenai segi tertentu dari penghayatan iman Kristiani.

8. Komunikasi dengan tradisi praktis Kristiani.

Konsultasi dengan tradisi kristiani tidak dibatasi pada tradisi tertulis saja, melainkan juga tradisi praktis. Tentu saja bahan tertulis mengenai praksis gereja termasuk juga di sini. 
9. Komunikasi dengan tradisi-tradisi lain.

Kesadaran akan keterbatasan penangkapan dan pengungkapan iman Gereja dalam segala bentuknya mendorong Gereja untuk berdialog dengan tradisi-tradisi lain, baik non-Kristiani ataupun tradisi non-religius. Hal ini semakin terasa penting bagi penghayatan iman Kristiani dalam masyarakat Indonesia yang plurireligius dan pluri-kultural.

10. Perumusan sintesis teologis.

Seluruh informasi dan konfrontasi dengan tradisi-tradisi kristiani maupun non-kristiani bermaksud untuk membantu merefleksikan pengalaman iman sendiri, sebagai partisipasi dalam pengalaman iman umat yang konkrit. Dalam tahap ini dirumuskan kembali keprihatinan iman atau hipotesis yang sudah dibuat pada momen Keprihatinan Iman, dengan menggunakan studi tradisi-tradisi yang baru saja dilaksanakan. Hipotesis dirumuskan menjadi suatu sintesis teologis yang dapat dipertanggungjawabkan secara ilmiah.

D. Momen rencana pastoral

Berteologi dengan titik tolak pengalaman aktual, setelah melalui komunikasi dengan berbagai tradisi, baik Kristiani maupun nonKristiani, akhirnya kembali ke pengalaman lagi. Dalam rangka kembali ke pengalaman, pernyataan-pernyataan teologis berhubungan dengan panggilan dan kehendak Allah. Momen rencana pastoral terdiri dari:

11. Merumuskan orientasi pastoral.

Sintesis teologis yang telah dirumuskan belum secara eksplisit mempunyai orientasi pastoral. Teologi fungsional mempunyai fungsi dalam komunikasi iman. Teologi fungsional memberikan sumbangan bagi pembinaan penghayatan iman umat, entah itu menyangkut pengungkapan maupun pelaksanaan iman. Karena itu, dirumuskanlah orientasi pastoral.

12. Menyusun program pastoral. 
Orientasi pastoral akhirnya harus dirumuskan secara lebih kontret lagi dalam suatu program pastoral. Di sini perlu dirumuskan juga kriteria evalusai terhadap program tersebut.

Para teolog pastoral di Indonesia juga menggunakan dan mengembangkan Metode Studi Kasus. ${ }^{50}$ Metode Studi Kasus adalah metode atau cara yang diterapkan untuk mengolah sebuah kasus. Metode Studi Kasus terdiri dari empat tahapan langkah-langkah: Deskripsi, Analisis, Interpretasi, dan Aksi (Aksi Pastoral, Aksi Pastoral-Teologis). ${ }^{51}$

Yang dimaksud dengan kasus adalah suatu kejadian atau peristiwa yang mengandung suatu permasalahan tertentu. ${ }^{52}$ Dalam Metode Studi Kasus, suatu kasus mula-mula dideskripsikan berdasarkan kaidah-kaidah tertentu, misalnya, disajikan secara pendek dan padat, ditulis dalam urutan yang jelas, dirumuskan seobyektif mungkin, dan tidak terlalu mengandung rumusan-rumusan analisis atau penafsiran. ${ }^{53}$ Setelah dideskripsikan, kasus tersebut dianalisis. Analisis merupakan upaya refleksi secara teliti dan kritis atas deskripsi kasus, dengan memperhatikan dinamika-dinamika yang terdapat di dalamnya. ${ }^{54}$ Interpretasi adalah tahapan ketiga dalam langkah-langkah Metode Studi Kasus yang mengandung penafsiran atas deskripsi kasus dan analisis, khususnya ditinjau dari sudut pandang teologis. Dalam tahap ini terjadi dialog antara peristiwa-peristiwa dalam kasus dengan tradisi/iman Kristen. ${ }^{55}$ Langkah terakhir dalam

50 Metode Studi Kasus di Indonesia dipopulerkan dan dikembangkan antara lain oleh South East Asian Graduate School of Theology (SEAGST) Institute of Advanced Pastoral Studies. Metode ini pernah digunakan sebagai metode pokok dari studi pastoral dalam pendidikan Doctor of Pastoral Studies yang diselenggarakan oleh SEAGST.

51 SEAGST Institute of Advanced Pastoral Studies bersama dengan Panitia Studi Kasus NTT, Studi Kasus Pastoral II - Nusa Tenggara Timur (Jakarta: BPK Gunung Mulia, 1990), hlm. 207.

52 SEAGST Institute of Advanced Pastoral Studies bersama dengan Panitia Studi Kasus NTT, Studi Kasus Pastoral II, hlm. 207.

53 SEAGST Institute of Advanced Pastoral Studies bersama dengan Panitia Studi Kasus NTT, Studi Kasus Pastoral II, hlm. 206.

54 SEAGST Institute of Advanced Pastoral Studies bersama dengan Panitia Studi Kasus NTT, Studi Kasus Pastoral II, hlm. 207.

55 SEAGST Institute of Advanced Pastoral Studies bersama dengan Panitia Studi Kasus NTT, Studi Kasus Pastoral II, hlm. 203, 207. 
Metode Studi Kasus adalah membuat perencanaan aksi pastoral terhadap semua pihak yang terkait dengan kasus tersebut. ${ }^{56}$

Selain Metode Studi Kasus, metode berteologi pastoral yang dilakukan secara klinis juga pernah diperkenalkan oleh beberapa teolog pastoral di Indonesia dalam pertemuan Studi Institut Persetia tentang Pendidikan Pastoral Klinis pada 1990. ${ }^{57}$ Dalam metode ini refleksi teologi pastoral dilakukan dari pengalaman pelayanan pastoral terhadap "living human documents" (manusia) yang biasanya dituliskan di dalam verbatim. ${ }^{58}$ Metode ini biasanya dipakai di dalam pendidikan pastoral yang disebut Clinical Pastoral Education (CPE).

Dari berbagai metode yang telah dikemukakan di atas dan yang digunakan di Indonesia saat ini, metode korelasi merupakan metode berteologi pastoral yang relevan bagi Indonesia. Mengapa demikian? Sebab metode ini berangkat dari pengalaman yang nyata, dan setelah berdialog dengan berbagai tradisi, kembali kepada pengalaman. Metode ini tidak bersifat abstrak atau teoritis saja, dan tidak juga kehilangan dimensi tradisinya. Karena berangkat dari pengalaman pastoral, refleksi teologi yang dikembangkan dengan metode korelasi akan lebih dekat dengan realitas.

Metode korelasi yang digunakan di Indonesia dapat terdiri dari berbagai model, seperti lingkaran pastoral yang dikemukakan oleh J.B. Banawiratma dan Tom Jacobs, Metode Studi Kasus, atau metode pastoral klinis yang dikembangkan melalui Clinical Pastoral Education.

\section{PELAYANAN PASTORAL}

Teologi pastoral tidak bisa dilepaskan dari pelayanan pastoral. Karena refleksi teologi pastoral yang relevan bagi Indonesia berangkat dari penga-

56 SEAGST Institute of Advanced Pastoral Studies bersama dengan Panitia Studi Kasus NTT, Studi Kasus Pastoral II, hlm. 203.

57 Lih. Phan Bien Ton, Mary Rajapono Manuain, Darmanto, eds., Studi Institut Persetia tentang Pendidikan Pastoral Klinis.

58 Verbatim adalah laporan tertulis tentang perjumpaan dan percakapan yang terjadi antara pelayan pastoral dengan orang yang dilayani. 
laman yang nyata, pelayanan pastoral menjadi penting dalam melakukan teologi pastoral di Indonesia. Bidang cakupan teologi pastoral akan menjadi sempit dan terbatas kalau pemahaman tentang pelayanan pastoral juga sempit dan terbatas. Sebaliknya, jangkauan teologi pastoral bisa menjadi luas kalau pemahaman tentang pelayanan pastoral juga luas.

Hommes menyatakan secara tegas keterkaitan antara teologi pastoral dan pelayanan pastoral. Menurut dia, teologi pastoral merupakan refleksi teologis atas dan dalam konteks pelayanan pastoral. ${ }^{59}$

Bagaimana pelayanan pastoral yang ada di Indonesia sampai saat ini? Penulis pernah membahas tentang hal ini. ${ }^{60}$ Menurut dia, pelayanan pastoral yang dilakukan gereja-gereja kita di Indonesia pada masa kini, secara khusus gereja-gereja Protestan, dapat dikatakan sempit dan terbatas. Sempit, karena pelayanan pastoral seringkali hanya ditujukan bagi orang-orang selaku individu atau kelompok kecil (misalnya keluarga), dan tidak terbuka kepada masyarakat. Karena itu pelayanan pastoral belum menyentuh semua kebutuhan dan persoalan yang dihadapi masyarakat pada saat ini. Terbatas, karena gereja-gereja kita pada umumnya masih menganggap pelayanan pastoral sebagai pelayanan yang lebih ditujukan kepada anggota-anggota gereja sendiri. Pelayanan ini menjadi pelayanan intern, yaitu pelayanan ke dalam, sehingga bersifat eksklusif.

Pelayanan pastoral yang sempit dan terbatas ini antara lain tergambar dalam DKG-PGI 2009-2014. Dalam dokumen itu dituliskan bahwa penggembalaan adalah pelayanan gereja untuk memelihara, menuntun, membimbing, memberi pengertian, mengarahkan dan menyadarkan warga bagi keutuhan hidupnya, agar ia hidup di dalam kasih pengampunan dan keselamatan Allah dalam Kristus. ${ }^{61}$

Buku-buku tentang pelayanan pastoral yang beredar dan banyak dipakai di kalangan sekolah-sekolah tinggi teologi di Indonesia juga ber-

59 Tjaard G. Hommes, “Pendahuluan,” hlm. 17.

60 Daniel Susanto, Pelayanan Pastoral di Indonesia pada Masa Transisi, hlm. 22-28.

61 Persekutuan Gereja-gereja di Indonesia, Dokumen Keesaan Gereja, hlm. 127. 
nada sama. Sebagai contoh, hal ini tergambar dalam buku tentang penggembalaan yang ditulis oleh M. Bons-Storm. Dalam buku ini Bons-Storm menyebutkan bahwa penggembalaan adalah (a) Mencari dan mengunjungi anggota jemaat satu-persatu; (b) Mengabarkan firman Allah kepada mereka, dalam situasi hidup mereka pribadi; (c) Melayani mereka, sama seperti sekiranya Yesus melayani mereka; (d) Supaya mereka lebih menyadari akan iman mereka, dan dapat mewujudkan iman itu dalam hidup sehari-hari. ${ }^{62}$

Mengapa pemahaman tentang pelayanan pastoral di Indonesia bisa menjadi begitu sempit dan terbatas? Menurut Susanto, hal ini bisa disebabkan karena beberapa hal. ${ }^{63}$ Pertama, pemahaman tentang pelayanan pastoral di Indonesia diwarisi dari Barat dan belum dikembangkan sesuai dengan konteks Indonesia. Pelayanan pastoral yang diwarisi dari Barat lebih mengarah kedalam dan bersifat individualistis. Ini sejalan dengan latar belakang dari para missionaris yang melayani di Indonesia pada waktu itu yang bersifat pietistis. ${ }^{64}$

Kedua, pengertian pelayanan pastoral di Indonesia masih didasarkan pada gambaran gembala dan domba dalam masyarakat agraris, seperti yang terdapat dalam beberapa bagian Alkitab, misalnya Yesaya 40:11, Mazmur 23, Yehezkiel 34, dan Yohanes 10. Bagian-bagian Alkitab ini ditafsirkan secara tradisional, sempit, dan terbatas, di mana domba-domba hanya dimengerti sebagai orang-orang percaya atau anggota gereja saja.

Ketiga, pelayanan pastoral di Indonesia masih mengikuti pembagian pelayanan gereja secara teoritis dan tradisional. Pembagian seperti ini bisa menyesatkan dan berdampak pada pengkotak-kotakan bidang pelayanan itu sendiri. Padahal, dalam praktik pelayanan itu tidak bisa dikotakkotakkan. Dalam pembagian pelayanan gerejawi seperti itu, pelayanan pastoral menjadi bidang pelayanan yang sempit dan terbatas. Pelayanan

62 M. Bons-Storm, Apakah Penggembalaan Itu?: Petunjuk Praktis Pelayanan Pastoral (Jakarta: BPK Gunung Mulia, 1979), hlm. 23.

63 Daniel Susanto, Pelayanan Pastoral di Indonesia pada Masa Transisi, hlm. 24-25.

64 Lih. S.A.E. Nababan, ed., Pergumulan Rangkap, hlm. 13. 
ini hanya dilakukan dalam bentuk verbal terhadap individu-individu dan kelompok kecil (seperti misalnya keluarga). Pelayanan terhadap masyarakat, apalagi terhadap lingkungan hidup, dianggap bukan bidang pelayanan pastoral. Padahal, di dalam pelayanan gerejawi, dimensi pastoral seharusnya mewarnai segalanya. Di dalam praktik, pelayanan gerejawi juga tidak dapat dikotak-kotakkan.

Pengertian pelayanan pastoral yang bersifat sempit dan terbatas ini sebenarnya tidak sesuai untuk Indonesia. Hal ini disebabkan karena persoalan-persoalan yang dihadapi di Indonesia jauh lebih kompleks dari hanya persoalan-persoalan individual. Ada persoalan-persoalan sosial dan persoalan-persoalan lingkungan hidup yang membutuhkan tanggapan pastoral.

Dalam studi pastoral belakangan ini, pemahaman tentang pelayanan pastoral yang sempit dan terbatas mendapatkan banyak kritik. Salah seorang teolog pastoral yang memberikan kritik adalah Stephen Pattison. Ia mengemukakan bahwa pelayanan pastoral yang diarahkan kepada individu-individu pada dasarnya tidak menghargai kebersamaan dan aspek sosial yang ada. ${ }^{65}$ Pelayanan pastoral tidak dapat dibatasi hanya pada individu belaka. Banyak dosa, penderitaan, dan kapasitas untuk bertumbuh yang akarnya berada di luar diri manusia selaku individu. Pelayanan pastoral juga tidak dapat ditujukan hanya bagi orang-orang Kristen saja. Dalam kenyataan, pelayanan Gereja, termasuk pelayanan pastoral, tidaklah dilakukan hanya untuk Gereja, tetapi untuk dunia. ${ }^{66}$

Masih banyak ahli yang memberikan kritik terhadap pemahaman tentang pelayanan pastoral yang sempit. Sebagai contoh, Ignatius L. Madya Utama menyatakan bahwa istilah "pelayanan pastoral" kerapkali dipersempit menjadi atau bahkan diidentikkan dengan pastoral care atau pelayanan peribadatan dan sakramental. ${ }^{67}$ Padahal, menurut Madya

65 Stephen Pattison, A Critique of Pastoral Care (London: SCM Press, 1988), p. 11.

66 Stephen Pattison, A Critique of Pastoral Care, hlm. 15-16.

67 Ignatius L. Madya Utama, “Berpastoral Seluas Realitas Kehidupan dengan Penuh Integritas," Spektrum 39 (2011): 54. 
Utama, berpastoral secara benar berarti melakukan pelayanan pastoral seluas realitas kehidupan. ${ }^{68}$ Pelayanan pastoral senantiasa menyentuh seluruh realitas kehidupan manusia dan lingkungan hidupnya serta seluruh realitas kehidupan masyarakat. ${ }^{69}$

F. Haarsma juga berpendapat bahwa penggunaan terbatas istilah pastorat bagi pemeliharaan jiwa perorangan atau kelompok kecil tidak dapat dibenarkan apabila berpangkal pada simbol biblis dari gembala. ${ }^{70}$ Pastorat tidak hanya mengarahkan diri pada pembebasan dari dosa, rasa bersalah, takut dan bimbang, putus asa dan benci, melainkan juga pada pembebasan dari kekuasaan ekonomi, masyarakat, kebudayaan dan politik yang menghalangi manusia menjadi manusia. Pastorat tertuju pada kota manusia dan pada manusia dalam kota itu. ${ }^{71}$

J.B. Banawiratma secara lebih rinci menulis tentang pelayanan pastoral sosial melalui 10 agenda pastoral transformatif menuju pemberdayaan kaum miskin dengan perspektif adil gender, HAM, dan lingkungan hidup. Kesepuluh agenda itu adalah: (1) Menggereja terbuka melalui komunitas basis kontekstual; (2) Berdialog dengan kaum miskin, dengan budaya-budaya, dan dengan agama-agama; (3) Mendasarkan gerakan pada Injil Yesus Kristus; (4) Penafsiran dan aksi: Pemberdayaan kaum miskin dengan perspektif adil gender, hak asasi manusia, dan lingkungan hidup; (5) Penafsiran dan pengalaman doa dan kontemplasi; (6) Refleksi kontekstual; (7) Perjumpaan lintas teks dan lintas konteks; (8) Pendekatan lintas ilmu; (9) Menempuh jalan kenosis Kristus yang menghambakan diri; (10) Afirmasi dan konfrontasi menuju transformasi. ${ }^{72}$

68 Ignatius L. Madya Utama, “Berpastoral Seluas Realitas Kehidupan dengan Penuh Integritas," hlm. 57.

69 Ignatius L. Madya Utama, “Berpastoral Seluas Realitas Kehidupan dengan Penuh Integritas," hlm. 71.

70 F. Haarsma, Pastorat dalam Dunia (Yogyakarta: Pusat Pastoral Yogyakarta, 1991), hlm. 24.

71 F. Haarsma, Pastorat dalam Dunia, hlm. 25.

72 J. B. Banawiratma, 10 Agenda Pastoral Transformatif: Menuju Pemberdayaan Kaum Miskin dengan Perspektif Adil Gender, HAM, dan Lingkungan Hidup (Yogyakarta: Kanisius, 2002). 
Pelayanan pastoral di Indonesia seharusnya dipandang secara holistik. Pelayanan pastoral holistik mempunyai cakupan pelayanan yang luas, tidak hanya terbatas bagi orang-orang secara individual, tetapi juga bagi masyarakat, bahkan bagi lingkungan hidup. Di kalangan Gereja-gereja Protestan di Indonesia, pelayanan pastoral bagi masyarakat agaknya kurang mendapat perhatian yang memadai, padahal pelayanan ini sangat dibutuhkan, apalagi masyarakat Indonesia bersifat pluralis. Masyarakat Indonesia terdiri dari bermacam-macam suku, budaya, bahasa, agama, dan seterusnya. Dalam kehidupan masyarakat sering terjadi konflik horisontal. Pelayanan pastoral bagi lingkungan hidup juga sangat penting bagi Indonesia karena persoalan lingkungan hidup, seperti bencana alam, kerusakan hutan, polusi, meningkatnya pemanasan bumi dan sebagainya, terjadi di Indonesia dan menantang tanggapan pastoral.

Susanto pernah menulis tentang pelayanan pastoral holistik. Menurut dia, pelayanan pastoral holistik tidak dilandasi oleh pemikiran teologi pastoral yang hanya berpegang pada gambaran antara gembala dan domba pada masyarakat agraris, seperti yang terdapat di dalam Alkitab, apalagi kalau gambaran itu ditafsirkan secara tradisional yang sempit dan terbatas. $^{73}$

Pelayanan pastoral holistik didasari oleh pemikiran teologi pastoral yang terbuka dan luas. Selain mengambil makna dari gambaran antara gembala dan domba yang ditafsirkan secara relevan untuk masa kini, pelayanan pastoral holistik dilandasi oleh pemikiran bahwa pelayanan pastoral pada dasarnya mencerminkan pemeliharaan Allah terhadap ciptaanNya. ${ }^{74}$ Menurut John Patton, istilah pastoral menunjuk pada sikap yang memelihara (care) dan mempedulikan (concern).${ }^{75}$ Apa saja yang dipelihara dan dipedulikan Allah? Tentu ciptaan-Nya yang terdiri tidak

73 Daniel Susanto, "Pelayanan Pastoral Holistik," dalam Sekilas tentang Pelayanan Pastoral di Indonesia, diedit oleh Daniel Susanto (Jakarta: Majelis Jemaat GKI Menteng Jakarta, 2008), hlm. 28.

74 Daniel Susanto, "Pelayanan Pastoral Holistik," hlm. 28.

75 John Patton, From Ministry to Theology: Pastoral Action and Reflection (Nashville: Abingdon Press, 1990), p. 65. 
hanya dari manusia secara individual tetapi juga dari masyarakat dan lingkungan hidup. Karena itu, dalam pelayanan pastoral holistik, Gerejamelalui pelayanan pastoralnya-juga dipanggil untuk memelihara ciptaan Tuhan yang berdimensi luas.

Di samping bidang cakupan pelayanannya yang luas, pelayanan pastoral holistik memandang manusia, masyarakat, dan lingkungan hidup sebagai satu kesatuan dari ciptaan Allah. Ketiganya tidak dipandang terpisah, tetapi saling berhubungan satu terhadap yang lain. ${ }^{76}$ Ron Miller mengingatkan bahwa pendekatan holistik tidak pernah melupakan saling keterhubungan secara fundamental dari semua fenomena yang ada. ${ }^{77}$ Sebaliknya, dalam pendekatan holistik keutuhan sangat ditekankan. Antara manusia secara pribadi, masyarakat, dan lingkungan hidup terdapat hubungan yang saling mempengaruhi.

Karena luasnya bidang cakupan pelayanan pastoral holistik, pelayanan ini tidak dapat didekati hanya dari disiplin teologi. Pelayanan pastoral holistik membutuhkan pendekatan interdisipliner. Persoalan manusia, masyarakat, dan lingkungan hidup akan diterangi dari berbagai disiplin ilmu yang berbeda, seperti psikologi, antropologi, sosiologi, ekologi, dan sebagainya. Walaupun demikian, peran teologi pastoral tetap tidak boleh dilupakan dalam pelayanan pastoral holistik.

\section{PENUTUP}

Pada akhir pembahasan ini dapatlah dikatakan bahwa teologi pastoral yang relevan bagi Indonesia adalah teologi pastoral yang dapat menjawab kebutuhan Gereja dan masyarakat Indonesia. Untuk itu, ada tiga hal yang perlu dikemukakan.

Pertama, teologi pastoral di Indonesia dapat dimengerti sebagai salah satu bidang studi atau cabang teologi yang mempelajari teori dan praktik

76 Daniel Susanto, “Pelayanan Pastoral Holistik,” hlm. 29.

77 Ron Miller, Caring for New Life: Essays on Holistic Education (Brandon, Vermont: Foundation for Educational Renewal, 2000), hlm. 22. 
pelayanan pastoral, di samping sebagai salah satu bentuk refleksi teologis yang bersifat kontekstual.

Kedua, metode korelasi merupakan metode berteologi pastoral yang revelan bagi Indonesia. Berbagai model dari metode korelasi, seperti Metode Studi Kasus dan metode pastoral klinis yang dikembangkan melalui Clinical Pastoral Education, dapat digunakan di Indonesia.

Ketiga, teologi pastoral tidak dapat dilepaskan dari pelayanan pastoral. Refleksi teologi pastoral yang relevan bagi Indonesia juga berangkat dari pengalaman pastoral yang nyata. Karena itu, agar jangkauan teologi pastoral di Indonesia menjadi luas, dibutuhkan pemahaman tentang pelayanan pastoral holistik yang mencakup care dan concern terhadap individu, masyarakat, dan lingkungan hidup.

\section{DAFTAR RUJUKAN}

Abineno, J. L. Ch. Pedoman Praktis untuk Pelayanan Pastoral. Jakarta: BPK Gunung Mulia, 1993.

Banawiratma, J. B. 10 Agenda Pastoral Transformatif: Menuju Pemberdayaan Kaum Miskin dengan Perspektif Adil Gender, HAM, dan Lingkungan Hidup. Yogyakarta: Kanisius, 2002.

"Teologi Fungsional - Teologi Kontekstual." Dalam Eka Darmaputera, ed., Konteks Berteologi di Indonesia: Buku Penghormatan untuk HUT ke-70 Prof. Dr. P.D. Latuihamallo. Jakarta: BPK Gunung Mulia, 1991, hlm. 47-64.

Bons-Storm, M. Apakah Penggembalaan Itu?: Petunjuk Praktis Pelayanan Pastoral. Jakarta: BPK Gunung Mulia, 1979.

Burck, J.R. \& R.J. Hunter. "Pastoral Theology, Protestant." In Dictionary of Pastoral Care and Counseling, eds. Rodney J. Hunter et al. Nashville: Abingdon Press, 1990, pp. 867-872.

Haarsma, F. Pastorat dalam Dunia. Yogyakarta: Pusat Pastoral Yogyakarta, 1991.

Heitink, Gerben. Praktische theologie: geschiedenis, theorie, handelingsvelden. Kampen: Uitgeverij Kok, 1993.

Hiltner, Seward. "Pengantar untuk Teologi Pastoral." Dalam Teologi dan Praksis Pastoral: Antologi Teologi Pastoral, eds. Tjaard G. Hommes \& Gerrit Singgih. Yogyakarta: Kanisius, 1992, hlm. 72-159. 
Preface to Pastoral Theology. Nashville: Abingdon Press, 1958.

Hommes, Tjaard G. "Pendahuluan." Dalam Teologi dan Praksis Pastoral: Antologi Teologi Pastoral, eds. Tjaard G. Hommes \& Gerrit Singgih. Yogyakarta: Kanisius, 1992, hlm. 15-17.

Madya Utama, Ignatius L. “Berpastoral Seluas Realitas Kehidupan dengan Penuh Integritas." Spektrum 39 (2011): 53-74.

. Gereja Partisipatif. Yogyakarta: Pusat Pastoral Yogyakarta, 2010.

Miller, Ron. Caring for New Life: Essays on Holistic Education. Brandon: Foundation for Educational Renewal, 2000.

Nababan, S.A.E., ed. Pergumulan Rangkap: Laporan Konsultasi Theologia, Sukabumi 23-28 Nopember 1970. Jakarta: Sekretariat Umum DGI, 1971.

Oden, Thomas C. Pastoral Theology: Essentials of Ministry. San Francisco: Harper \& Row, 1983.

Pattison, Stephen. A Critique of Pastoral Care. London: SCM Press, 1988.

Patton, John. From Ministry to Theology: Pastoral Action and Reflection. Nashville: Abingdon Press, 1990.

Persekutuan Gereja-gereja di Indonesia. Dokumen Keesaan Gereja: Persekutuan Gereja-gereja di Indonesia (DKG-PGI) 2009-2014. Jakarta: Persekutuan Gereja-gereja di Indonesia, 2010.

Phan, Bien Ton, Mary Rajapono, Darmanto, eds. Studi Institut Persetia tentang Pendidikan Pastoral Klinis - Salatiga, 2-10 Juni 1990. Jakarta: Persetia, 1991.

SEAGST Institute of Advanced Pastoral Studies bersama dengan Panitia Studi Kasus NTT. Studi Kasus Pastoral II - Nusa Tenggara Timur. Jakarta: BPK Gunung Mulia, 1990.

Susanto, Daniel. "Clinical Pastoral Education: Sebuah Model Pendidikan Pastoral di Indonesia." Jurnal Teologi Proklamasi 8 (Mei 2009): 53-67. Pelayanan Pastoral di Indonesia pada Masa Transisi - Orasi Dies Natalis ke-72 Sekolah Tinggi Teologi Jakarta. Jakarta: UPI STT Jakarta, 2006.

. "Pelayanan Pastoral Holistik." Dalam Sekilas tentang Pelayanan Pastoral di Indonesia, ed. Daniel Susanto. Jakarta: Majelis Jemaat GKI Menteng Jakarta, 2008, hlm. 25-40.

. "Sekilas tentang Teologi Pastoral di Indonesia." Dalam Bunga Rampai Teologi dan Pelayanan Pastoral, ed. Daniel Susanto. Jakarta: Majelis Jemaat GKI Menteng, Jakarta, 2003, hlm. 5-14. 
Tillich, Paul. Systematic Theology, vol. I. Chicago: The University of Chicago Press, 1951.

Systematic Theology, vol. II. Chicago: The University of Chicago Press, 1957.

Tracy, David. "The Foundations of Practical Theology." In Practical Theology, ed. Don S. Browning. San Francisco: Harper \& Row, 1980, hlm. 61-82.

Wongso, Peter. Theologia Penggembalaan. Malang: Seminary Alkitab Asia Tenggara, 1991. 